\title{
Can Images Transform a Poem? When I Heard the Learn'd Astronomer: An Example of a Poetry Picturebook
}

DOI: $10.1080 / 13614541.2013 .751290$

María del Rosario Neira-Piñeiro

\begin{abstract}
This article analyzes When I Heard the Learn'd Astronomer, which we consider to be an example of a poetry picturebook, a kind of text belonging to the field of children's literature which is characterized by the interaction between a poetic text and a sequence of illustrations. In this case, visual narrative adds a story to the poem and incorporates some visual poetic structures. Text and pictures become a unit, whose sense is created through the complex interaction of visual and verbal. The result is a new work incorporating a personal interpretation of the original Walt Whitman poem, adapted for child readers.
\end{abstract}

\section{To cite this article:}

Neira-Piñeiro, María del Rosario (2013): Can Images Transform a Poem? When I Heard the Learn'd Astronomer: An Example of a Poetry Picturebook, New Review of Children's Literature and Librarianship, 19:1, 14-32

To link to this article: http://dx.doi.org/10.1080/13614541.2013.751290 